\title{
Developing Student Worksheets based on Problem Based Instruction on Environmental Pollution Material
}

\author{
Emilia Sartika ${ }^{1}$, Nizkon $^{2}$, Sulton Nawawi ${ }^{3 *}$ \\ 1,2,3 Program Studi Pendidikan Biologi, FKIP, Universitas Muhammadiyah Palembang \\ Coressponding Author. E-mail: \\ 1emiliasartika69@gmail.com \\ 2nizkonaslim@gmail.com \\ 3sulton.bio@gmail.com
}

Received: January 2nd 2020

Accepted: July 26st, 2020

Online Published: July $28^{\text {th }}, 2020$

\begin{abstract}
Student worksheets are a learning tool that plays an important role in learning, but in schools have not used student worksheets in learning. This study aims to reveal (1) how the characteristics of student worksheets based on Problem Based Instruction models on environmental pollution material (2) how the feasibility of student worksheets based on Problem Based Instruction models on environmental pollution material (3) how practicality of student worksheets based on Problem Based Instruction models on environmental pollution material. Research refers to the Borg and Gall development model to the seventh stage, namely potential and problems, data collection, product design, design validation, design revision, product testing, product revision. The research instruments used in data collection were interviews, observation, and questionnaires. The data obtained were then analyzed by quantitative descriptive analysis. The characteristics of student worksheets teaching materials developed using the Problem Based Instruction model on environmental pollution materials are arranged systematically, interestingly, and clearly. Students can learn independently; the developed student worksheets does not depend on other media, and students can interact directly with the environment. Based on the feasibility trial student worksheets is in the "Very feasible" category. Material experts with grades $\mathrm{X} \geq 33$ categories are very feasible, media experts $X \geq 45$ categories are very feasible, linguists $X \geq 18$ categories are very feasible, expert practitioners $X \geq 42$ categories are very feasible, and students' responses $X \geq 33$ categories are efficient. The results obtained can be concluded that the developed student worksheets meets the very feasible category, so it is suitable for use.
\end{abstract}

Keywords: development student worksheets; problem based instruction; environmental pollution

How to cite this article :

Sartika, S., Nizkon, N., \& Nawawi, S. (2020). Developing Student Worksheets based on Problem Based Instruction on Environmental Pollution Material. IJIS Edu : Indonesian Journal of Integrated Science Education, 2(2), 131-142. doi:http://dx.doi.org/10.29300/ijisedu.v2i2.2650 


\section{INTRODUCTION}

The development of science and technology nowadays creates tight competition in all aspects of life. The existence of this development has a very big impact, one of which is in the world of education which has a significant impact in the development of science. To overcome this, we need to create excellent and competitive human resources. Therefore, human resources (HR) in a country are determined by the educational process organized by the State.

Education plays a pivotal role in creating smart, broad-minded generation who are able to solve the problems both now and in the future. According to Zubaidah (2017) in the 21st century, the role of the teacher shifted from the pattern of "inculcation of knowledge" to the role of a guide, director of discussion and a measure of student learning progress. The main objective of learning in 21 st century is to build individual learning abilities and support the development of students into lifelong, active, and independent learning. According to Ikhsan, Sutarno, \& Prayitno (2016), one of the competencies that teachers need to have in carrying out their duties is to develop teaching materials as a means to prepare the course of learning activities.

Through education, this nation can develop to more advanced state and create intelligent and competitive human resources, so that we can compete with developed countries around the globe. In the field of education, increasing human resources can be achieved through the learning process. Various attempts were made by the government to improve human resources through improving the quality of education. The curriculum has changed in the last few years. The changes in curriculum are efforts to improve the quality of education including the development of several methods, models, approaches, and learning strategies. In this case the government developed the existing curriculum, known as the Competency Based Curriculum and the Education Unit Level Curriculum into the 2013 Curriculum.

The implementation of the 2013 curriculum included strengthening spiritual attitudes, social attitudes, knowledge and skills in the learning process. The learning process is the main key in student learning activities. In the 2013 curriculum, learning activities need to use principles: 1) learner-centered, 2) developing student creativity, 3) creating fun and challenging conditions, 4) including value, ethics, aesthetics, logic, and kinesthetic, and 5) providing diverse learning experiences through the application of various learning strategies and methods that are fun, contextual, effective, efficient and meaningful (Muhammad, 2017).

An educator (teacher) in education has a very large role that requires teachers to have strategy and creativity in the learning process. The process of learning biology in the classroom must be designed optimally to achieve learning goals. The teacher can use teaching materials to support the learning process.

An education system that applies the concept of independent learning, learning materials that are specifically designed to be learned by students independently are required, therefore professional staffs who are able to develop independent learning materials are needed. The development of teaching materials is important to be done by educators so that learning is more effective, efficient, and does not deviate from the competencies that will be achieved. Therefore, teaching materials are very important to be developed in an effort to improve the quality of learning. One of the teaching materials that will be developed is the student worksheet.

Student worksheets are sheets containing material, summaries, and assignments that must be accomplished by students. The role of student worksheets in learning one of them is as teaching material that can minimize the role of educators but more activates for students. The usefulness of the Student Worksheet which can help teachers in directing students to be able to find concepts through their own activities or within groups, can be used to develop process skills, developing scientific attitudes and arousing students' interest in the natural surroundings, making it easier for teachers to see the success of students in achieving learning goals, and facilitating teachers in managing the learning process because the learning process is usually in the hands of the teacher (teacher center) but now turns into learning activities held by students (student center).

The results of interviews with Biology teachers at SMA Negeri 1 Pendopo showed that in the learning process, printed textbooks were used. However, they have never used student worksheets in the matter of environmental pollution based on the Problem Based Instruction learning model. Therefore the researcher offers student worksheets based on Problem Based Instruction learning model, 
because student worksheets has the advantage of making learning media stand up for students, increasing student activities in participating in teaching and learning activities, practical and affordable prices, and the material is more concise and includes the whole Theory.

The results of observation in SMA Negeri 1 Pendopo revealed that the school needed student worksheets on Environmental Pollution material to add insight to student knowledge. It was also one of the natural science materials in SMA in Class $\mathrm{X}$ that was related to this research namely Environmental Pollution material in the 2013 Curriculum included in Basic Competence 3.11. This material is directly related to daily life so students can learn directly. One way to improve student understanding and learning outcomes is by developing good teaching materials. One of the teaching materials that can be developed is the Student Worksheet based on the Problem Based Instruction learning model.

The use of Problem Based Instruction learning model is a good learning model to direct and generate student interest in processing information in their minds and compiling their prior knowledge. In addition, the results of interview with biology teacher showed that the learning outcomes of semester 1 and 2 of class X were above the KKM score of 65 . However, the scores of Environmental Pollution material was lower compared to other chapters.

Student Worksheet based on Problem Based Instruction learning model on environmental pollution material is very suitable because the learning model based on Problem Based Instruction is a student-centered which was very helpful to solve everyday problems (authentic) so that students were accustomed to everyday real situations. According to Dewi (2016), the syntax of learning based on Problem Based Instruction learning model are as follows (1) introducing students to the problem, (2) organizing students to learn, (3) helping independent and group research, (4) developing and display existing work, and (5) analysis and evaluation of the problem solving process.

\section{RESEARCH METHOD}

This study was research and development research, while the development was in the form of student worksheets based on the Problem Based Instruction learning model. The R\&D used referred to the Borg and Gall development model. This model is divided into 10 main stages, namely: potential and problems, data collection, product design, design validation, design revisions, product trials, product revisions, product trials, final product revisions, and mass production. However, this development did not reach the stage of mass production but only to the revision of the product because it was for research necessity only. This was in accordance with what was stated by Sani et al (2018: 251) which was for the research needs of students of educational programs so that the intended target could be minimized so that the time and cost of implementation could be met (potential and problems, data collection, product design, design validation, design revisions, product trials, product revisions).

Preliminary data collection techniques to look for potential and problems that existed in school were field observations, interviews, and questionnaires to test the validation of student worksheets eligibility. The instruments of this study were material expert assessment instruments, media expert evaluation instruments, language expert evaluation instruments, practitioner expert evaluation instruments and the feasibility instruments of student worksheets teaching materials in terms of students' opinions. Data analysis used the calculation developed by Mardapi.

The validation assessment of the overall product feasibility indicator is based on the score of the eligibility categorization table as table 1.

Table 1. Eligibility Categories

\begin{tabular}{lll}
\hline No. & Score Range & Category \\
\hline 1. & $\mathrm{X} \geq \bar{X}+1 . \mathrm{SBX}$ & Very feasible \\
\hline 2. & $\bar{X}+1 . \mathrm{SBX}>\mathrm{X} \geq$ & Feasible \\
& $\bar{X}$ & \\
\hline 3. & $\bar{X}>\mathrm{X} \geq \bar{X}_{-}$ & Moderate \\
& $1 . \mathrm{SBX}$ & \\
\hline 4. & $\mathrm{X}<\bar{X}-1 . \mathrm{SBX}$ & Less \\
\hline
\end{tabular}

(Source: Mardapi, 2007:122)

\section{RESULTS AND DISCUSSION Results}

1. Potential and Problems

Based on field studies carried out in SMA Negeri 1 Pendopo, it was found that only teaching materials in the form of printed books provided from school. Therefore researchers chose the school as a place of research with the 
aim to encourage students to be more actively engaged in the learning process when they had teaching materials other than printed books provided from school, such as teaching materials in the form of student worksheets.

From the results of interviews with Biology subject teachers get the results of school accreditation, school curricula, learning materials in the class that scores the lowest, teaching materials that are often used during learning and about the learning model used.

From the results of the Questionnaire submitted to students whose aim is to retrieve data about teaching materials that were often used in learning in the form of mandatory handbooks (textbooks), students needed teaching materials such as completed pictures in accordance with the material being taught such as teaching materials in the form of student worksheets. From the questionnaire filled out, some students said that the teacher during the learning process also used Discovery Learning Model.

\section{Data Collection}

The data collected in this study were information related to research needs. From the results of data collection we got the target of this study, which was a class X student of Natural Sciences 1 because the grade was higher compared to other classes.

The selection for the material was also based on the analysis of daily tests of students in the academic year 2017/2018 which showed that the preparation of biological material related to environmental pollution in SMA Negeri 1 Pendopo was the lowest value compared to other materials.

According to Diniaty \& Atun (2015), the systematic development of Student Worksheets based on the Problem Based Instruction learning model consisted of Title, Table of contents, concept map, instructions for using student worksheets, basic competencies, core competency, Indicators of Competency Achievement, learning objectives, student training based on the syntaxes of the Problem Based Instruction learning model with problem orientation, organizing learning tasks, helping independent and group research, developing and displaying work, analysis and evaluation of problem solving processes, conclusions, and questions students must work on.

3. Product Design

Results of the analysis of needs based on Problem Based Instruction was developed based on the syllabus and lesson plans for environmental pollution material found in the basic competencies 3.11 in 2013 curriculum syllabus. Then, indicators and learning objectives were considered.

Student Worksheet was a printed teaching material consisted of several types of components including: Title, Table of contents, concept map, instructions for using student worksheets, basic competencies, core competency, Indicators of Competency Achievement, learning objectives, student training based on the syntax of learning models Problem Based Instruction, namely problem orientation, organizing learning tasks, helping independent and group research, developing and displaying work, analysis and evaluation of problem solving processes, conclusions, and questions students had to work on.

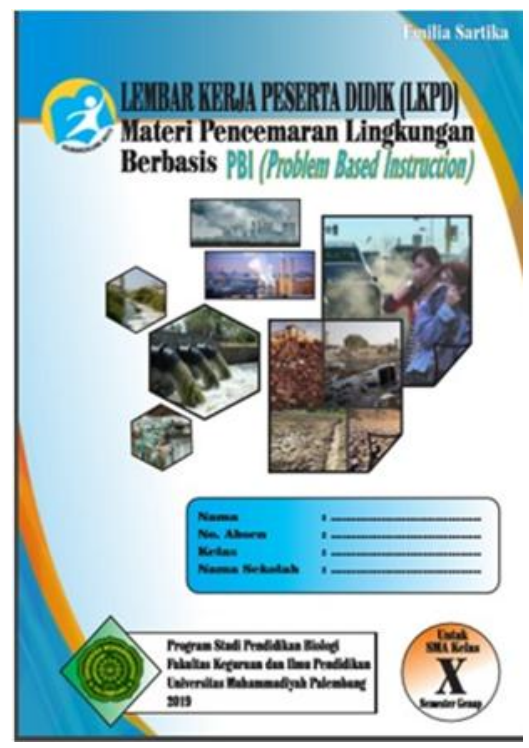

Figure 1. Student Worksheets Cover

\section{Design Validation}

Designs that had been created in the third stage above were not applicable yet in classroom learning because it had to go through instrument validation and initial design validation first. The design validation created was validated to test the feasibility of student worksheets. Validation was done using questionnaires given to material experts, media experts, linguists, biology teachers and students. To find out the feasibility of student worksheets, researchers handed out questionnaires to class $\mathrm{X}$ students as respondents, then validated again to experts so that the final product was finally ready for use. 
Design validation was a process of activities to obtain a product design in the form student worksheets of a Problem Based Instruction based on a feasible use in the biology learning process. Design validation used was content validation, where the designs that had been made were examined and analyzed in advance by the validator of media experts, material experts, linguists, and biology teachers as practitioners before being tested on small groups in the field. The determination of the feasibility of a product revision was carried out using Mardapi calculation in order to obtain an student worksheets that is suitable for use in the learning process as a product of this development research in table 2.

Table 2. Expert assessment of validation test

\begin{tabular}{cccc}
\hline No & Validator & Score & Category \\
\hline 1. & Material experts & $40 \geq 33$ & Very feasible \\
& & \\
\hline 2. & Media experts & $49 \geq 45$ & Very feasible \\
& & \\
\hline 3. & linguists & $22 \geq 18$ & Very feasible \\
\hline 4. & Teachers of the subject & $54 \geq 42$ & Very feasible \\
\hline
\end{tabular}

a. Feasibility of Student Worksheets according to Material Expert

From the results of the material expert validation, a value with the category $X \geq 33$ which was $40 \geq 33$ was obtained, which means it was in the very feasible category. After the results of the material validation were obtained, it was stated that the product was suitable for use in the learning process. In this study there were eleven indicators, namely the completeness of the content, the breadth of the material, the suitability of the indicator, the suitability of the material with the learning objectives, the accuracy of the principles and theories, the systematic sequence of the material, the suitability of the questions with the Problem Based Instruction model.

The material expert assessed the student worksheets that had been made by the researcher and filled in the questionnaire sheets that had been given from the researcher. As for the parameters assessed, namely: completeness of the contents (valued 4), the breadth of the material's (valued 4), the suitability of the indicator's (valued 4), the suitability of the material with the learning objectives (valued 4), the accuracy of the principle and theory of its (valued 3), the order of the material (valued 4), the suitability of the questions Based Instruction (valued 17), and therefore the total value was 40

Table 3. Comments and suggestions from material experts

\begin{tabular}{cc}
\hline No. & Comment and suggestion \\
\hline 1. & Please pay attention to writing procedure \\
2. & The material has represented the indicators \\
& of learning \\
\hline
\end{tabular}


b. Feasibility of Student Worksheet according to Media Expert

From the results of the validation of media expert, it was obtained a value with the category $X \geq 45$ in range $49 \geq 45$ which means it was categorically very feasible. Considering the result of the material validation, it was concluded that the product was suitable for use in the learning process.

In this study, media experts assessed the evaluation of 16 indicators, namely: the layout elements on the front cover, center of view, the balance of the layout elements, the size of the title on the front cover of student worksheets, number of letter types, print fields and proportional margins, appropriateness (shape, color, size of layout elements), illustrations, spacing between lines of normal text, placement of consistent layout elements, appropriateness and accuracy of illustrations with the material, sufficient space on the worksheet so students can write a translation on the worksheet, introduction, list contents and bibliography.

From the result of the calculation of media validation, it was concluded that the student worksheets that had been made by the researcher was feasible to use, but there were some things that needed to be improved. Comments from the media expert validator as in table 4:

Table 4. Comments and Suggestions from Media Expert

\begin{tabular}{cc}
\hline No. & Comment and suggestion \\
\hline 1. & The picture on the cover is oversized \\
2. & There is too much blank space mainly in \\
the Indicator of Competency Achievement \\
and the goal of learning
\end{tabular}

c. Feasibility of Student Worksheet according to Language Expert

Based on table 4.5, language validation was consisted of six indicators namely suitability with the level of development of students' thinking, suitability with the level of emotional and social development of students, students' understanding of messages, sentence structure determination, language determination and spelling determination. In table 4.5, it was explained that the total obtained was 22 within the range of $22 \geq 18$ which means that it was categorically very feasible.

From the results of the validation of linguists on teaching materials in the form of student w orksheets with environmental pollution material, it can be concluded that student worksheets teaching materials were very suitable to be used as teaching materials in school learning.

d. Eligibility of Student Worksheet according to Education Practitioners

The results of the validation of the education practitioners were carried out by two
Biology teachers: practitioner I and practitioner II. The purpose of the validation of education practitioners was to obtain data in the form of suggestions on the contents, layout, presentation, language used and the functions in the learning process. The results of the validation by Biology teacher at SMA Negeri 1 Pendopo showed that the score from practitioner I was $X \geq 42$ within the range of $54 \geq 42$ and practitioners II with the score $X \geq 42$ within the range of $52 \geq 42$ which means it was very feasible. The result of the material validation supported the product to be suitable for use in the learning process

At this stage practitioner I assessed student worksheets and filled out the questionnaire given by the researcher. There were 6 aspects of education practitioners' assessments conducted by Biology Teachers, namely: Conformity basic competencies \& core competency (Valued 4), appropriateness indicators of achievement (valued 4), appropriateness of learning objectives with $\mathrm{KD}$ and indicator (valued 4), component worthiness of contents (valued 20), component presentation (valued 11) and aspect components the language (valued10), and the total value was 54. 
At this stage practitioner II assessed the student worksheets and filled out the questionnaire sheets that have been given by the researcher. There were 6 aspects of education practitioners' assessments conducted by Biology Teachers, namely: Conformity basic competencies \& core competency (valued 4), appropriateness indicators of achievement (valued 4), appropriateness of learning objectives with $\mathrm{KD}$ and indicator (valued 4), component worthiness of contents (valued 18), component presentation (valued 12) and aspect components the language (valued 10), and the total score was 52. The comments of the practitioners towards student worksheets are presented in Table 5

Table 5. Comments and Suggestions from Practitioners

\begin{tabular}{c}
\hline Comment and suggestion \\
\hline The scientific terms should be italicized \\
\hline
\end{tabular}

\section{Design Revision}

The student worksheets design which was validated by experts was revised after two consultations, each corrected by the researcher referring to the comments provided by expert validators. After being corrected according to the instructions, it was consulted again to the experts. The revised results that had been approved by expert validators were then tested on a small group.

\section{Product trials}

After the final product was declared feasible to be tested for small groups in this study, the next stage was that the researchers conducted a field trial. The steps taken were using student worksheets in the process of learning Biology of Environmental Pollution material. At this trial stage, students filled out the student questionnaires regarding student worksheets. This field trial consisted of a small group test conducted at class X.IPA.1 which consisted of 32 students. The results of this small group trial were then used as material to determine the feasibility of student worksheets in the final stage by applying Mardapi formula.

The results of student questionnaires aimed to collect data related to the use of learning student w orksheets which included design on the front cover. student worksheets added interest in learning the material, the layout of images and writing on the front cover of student worksheets was appropriate and well ordered, the design on the table of contents and introduction was eyecatching, the design of the activity sheet added interest to learn the material, the color of the text or text used on the worksheet was considerable and engaging, the pictures added interest to learn the material, the material in student worksheets was complete, student worksheets provided can motivate students, student worksheets invited students to be active in learning process, learning material in student worksheets referred to or according to basic competencies \& core competency, student worksheets developed students' thinking abilities and solves problems. The students submitted the questionnaires on June 18, 2019.

In this study, the results of the questionnaires from the 32 students were in very feasible category, which means that the product was feasible into use.

7. Product Revision

The final stage of developing Problem Based Instruction based student worksheets on Environmental Pollution material in this study was product revision. Revision was made to student worksheets which had been tested by small groups. The purpose of the final product revision was to correct the deficiencies that still existed in the student worksheets after the results of the field trial. After distributing questionnaires to 32 students commenting on the student worksheets, they said that the product was very appealing and enabled the students to look for information about environmental pollution, the student worksheets was easy to understand, the student worksheets color was also good, each page added an interest in doing it, and the student worksheets that could motivate students to learn. This revision was adjusted to the condition in the field. Determination of the feasibility of product revision was done by using Mardapi calculation so that the final product was suitable for use in 
the learning process as a product of this research development

\section{Discussion}

\section{A. Characteristics of Student Based Worksheet Problem Based Instruction}

The product using the Biology Problem Based Instruction with environmental pollution material had been successfully developed. student worksheets developed using Basic Competence 3.11 analyzing data on environmental changes and the impact of these changes on life. It was presented in one student worksheets consisting of three sub-chapters namely water pollution, air pollution, and soil pollution. student worksheets was compiled in an integrated manner according to 2013 curriculum with a learning model Based on Problem Based Instruction.

Student Worksheet (student worksheets) used in this study was in the form of printed materials, it was hoped that students could easily understand the material. student worksheets was composed of three main parts, namely introduction consisting of core competencies, basic competencies, instructions for using student worksheets, and concept maps. The contents section consisted of teaching materials, practice questions and bibliography. The results showed that student worksheets helped students learn independently, Problem Based Instruction based models encouraged students to be more active because here students must be sensitive, students could learn student worksheets anywhere and found out about events that occurred around them, as well as learning experiences gained by students themselves would be remembered longer.

Student Worksheets used at the school had not specifically used the same model or approach with the characteristics of the material and learning objectives to be achieved, to achieve the learning objectives. Therefore student worksheets developed as teaching material which was a supplement textbook.

The development of student worksheets could help students solve problems and become independent in learning, there were a number of learning methods that were often difficult for students to explain. Model Problem Based Instruction was a learning model that used a problem in everyday life, not only focused on mastery of the material. The Problem Based Instruction learning model centered on student activities. This model was one of the learning models that teachers could use in activating students in learning.

According to Hidayat (2016), the Student Worksheet was composed of three parts, namely introduction consisting of core competencies, basic competencies, instructions for using student worksheets, concept maps, and indicators of competency achievement. The contents section which consisted of teaching materials, evaluation questions and conclusions consisted of a bibliography. Meanwhile, according to Diniaty \& Atun (2015) there was a systematic procedure for creating Student Worksheets namely a) title, b) introduction, c) objectives, d) tools and materials, e) work steps, f) observation tables, g ) questions, h) conclusions.

According to Marsa, Hala, \& Mushawwir (2016), the Student Worksheet was an independent learning package that included a series of learning experiences that were planned and systematically designed to help students achieve their learning goals. The main goal of student worksheets was to form effective interaction between students and teachers, so as to increase student learning activities in improving learning achievement

The development of student worksheets could help students solve the problems and become independent in learning, there were a number of learning materials that were often difficult for students to explain. Problem Based Instruction is one of the learning methods used to stimulate students to think highly in situations oriented to real-world problems.

According to Ermi (2016) the Student Worksheet had benefits which are a) It helped teachers in directing their students to be able to find concepts through their own activities or within groups, b) It could be used to develop process skills. It developed scientific attitudes and arouse students' interest in the natural surroundings, c) it facilitated the teacher to see the success of students in achieving learning goals, d) it facilitated the teacher in managing the learning process because the learning process which was usually in the hands of the teacher (teacher center) but now turned into learning activities held by students (student center).

B. Feasibility of Student Worksheets Based on Problem Based Instruction Model on Environmental Pollution Material 
Development of student worksheets teaching materials based on Problem Based Instruction model on class $\mathrm{X}$ environmental pollution material, developed based on the research and development stages designed by Borg and gall. The assessment data obtained from the validator served as a reference for revising the product, so as to produce a viable product. The developed product design was assessed by the validator using a validation sheet. The results of the assessment of all aspects were measured using Likert scale. From the results of expert validation, educator practitioners and students showed that the student worksheets was appropriate with the goals developed because it was very good according to material expert, media expert, linguist, but needed some improvement according to the comments of each expert through the first stage student worksheets revision.

Eligibility for Student Worksheets according to Material Expert

Based on the results of the validation of the material with eleven indicators, namely the completeness of the content, the breadth of the material, the suitability of the indicator, the suitability of the material with the learning objectives, the accuracy of the principles and theories, the systematic sequence of the material, and the suitability of the questions with the Problem Based Instruction learning model, material expert stated that student worksheets teaching materials had been designed using proper writing procedures, improving concept maps and adding questions to questions in air pollution.

In table 2 it was explained that the total value or score obtained was 40 which showed 40 $\geq 33$ included in the category of very feasible. According to Budiono \& Susanto (2006), the criterion of the material aspects used by student worksheets was information about the subject matter supplemented by pictures and student worksheets gave students the opportunity to complete individually. Content material that was relevant to the theme or concept being studied was flexible because student worksheets material could be learned by students in different ways and speeds (Lasmiyati, 2014). Meanwhile, according to Susiolo (2016), aspects of the feasibility of the material or content which included the conformity with the competency standards, and basic competency, suitability with child development, conformity with the needs of teaching materials, the truth of the substance of learning materials, and the benefits to add insight.

From the results of the material expert validation of teaching materials in the form of student worksheets with environmental pollution materials and revisions based on comments given by material experts it could be concluded that student worksheets teaching materials were very suitable to be used as teaching materials in school learning.

1. Feasibility of Student Worksheet according to Media Expert

Based on the results of media validation with sixteen indicators, it was explained in table 2 that the total values or scores was 49 which in range $49 \geq 45$ which mean it was very feasible. Media expert commenting on student w orksheets teaching materials said that the image cover did not represent water, air, soil pollution, on the cover add subjects, the answer column was enlarged, added a table of contents and bibliography

From the results of the media expert's validation of teaching materials in the form of student worksheets with environmental pollution material along with the revisions based on comments given by media experts, it could be concluded that student worksheets teaching materials were very suitable to be used as teaching materials in school learning. In accordance with Lasmiyati's research (2014), criteria for the aspect of media used in student worksheets were w riting style. student worksheets was designed to be interesting, easy to learn and could answer the needs of course which increase student motivation to learn. According to Susiolo (2016), aspects of the feasibility of the media or presentation were including the clarity of objectives (indicators) to be achieved, the order of presentation, its capability to increase motivation, attractiveness, interaction (providing stimulus or response), completeness of information, use of fonts (type and size), layout, illustrations, images, photographs and display designs.

\section{Feasibility of Student Worksheet} according to Linguists

Based on the results of language validation with six indicators, it was clear that in table 2 the total values or scores obtained was 22 which showed $22 \geq 18$ which was in the category of very feasible. 
From the results of the validation of linguists on teaching materials in the form of student worksheets with environmental pollution material, it could be concluded that student worksheets teaching materials were very suitable to be used as teaching materials in school learning. According to Budiono \& Susanto (2006), the feasibility aspect of the language used in student worksheets was that the language used must be interesting and always stimulated students to think. Meanwhile, according to Susiolo (2016), aspects of language eligibility were including readability, clarity of information which met the rules of Indonesian language, the use of language effectively and efficiently (clearly and briefly).

\section{Feasibility of Student Practitioner Worksheet}

Based on the results of the validation of biology teachers as practitioners with fourteen indicators, it was explained in table 2 that the total scores obtained from practitioner I was 54 within the range of $54 \geq 42$ and practitioner II was 52 within the range of $52 \geq 42$, which means that it was categorically very feasible.

The feasibility of student worksheets based on the Problem Based Instruction learning model on environmental pollution material was tested through the stages of expert validation, practitioner assessment, and students. The revision of the students' worksheets was carried out based on suggestions from practitioner experts.

The eligibility criteria from material expert consist of aspects, such as material suitability, the scope of learning material for student worksheets, the accuracy of the material, learning support material, conformity with the Problem Based Instruction learning model, the content of the material, contains insight into productivity and the function of teaching material in learning. The eligibility criteria from media expert consisted of aspects, such as the presentation component, the feasibility of graphics and the benefits of teaching materials. The eligibility criteria from linguist consisted of aspects, namely the suitability of the intelligence of students, communicative and straightforward. and the feasibility of the teacher includes aspects namely the component of the feasibility of the content, the linguistic component, the component of presentation and the reflection of the student worksheet. based on the results of validation from experts and teacher worksheets of students (LKPD) that have been made and developed are good and have met the eligibility criteria (Martiningsih, et al, 2018).

According to Susiolo (2016) the student worksheet was a printed teaching material designed to be studied independently by learning participants. Student worksheets were also called media for independent learning because they had been equipped with instructions for self-study. Good teaching materials were teaching materials arranged using good and interesting language, stimulating students to be actively engaged in thinking process, information about the subject matter that was equipped with pictures and reflecting the level of student ability. Learning media was the most important thing for a class to take place, creative, communicative and innovative learning in improving student learning outcomes (Efendi, 2015).

\section{Practicality of Student Worksheets Based on Problem Based Instruction Models on Environmental Pollution Materials}

Based on the results of student questionnaires with eleven indicators, it was explained in the table that the total scores or values obtained from 32 students was in category of very practical. Students commented towards student worksheets teaching materials that they were very interesting, and could make students look for information about environmental pollution, student worksheets was easy to understand, student worksheets colors were also good and each page added interest to do it, and it motivated students to learn.

From the results of 32 student questionnaires on teaching materials in the form of student worksheets with environmental pollution material, it could be concluded that student worksheets teaching materials were very practical to be used as teaching materials in school learning.

\section{CONCLUSION}

The Student worksheets based on the Problem Based Instruction model developed was for practical activities which consisted of components such as front cover, identity page, table of contents, concept map, instructions for using student worksheets, basic competencies, competencies core, competency achievement 
indicators, learning objectives. The contents section consisted of teaching materials, practice questions and bibliography. Problem Based Instruction based student worksheets had stages by following the steps of the Problem Based Instruction learning model consisting of (1) introducing students to problems, (2) organizing students to learn, (3) helping independent and group research, (4) developing and displaying existing work, and (5) analysis and evaluation of problem solving processes.

Validation carried out by material expert obtained a value of $X \geq 33$ with a very decent category, media expert gave a value of $X \geq 48$ with a very decent category, a linguist gave an $\mathrm{X}$ $\geq 18$ with a very decent category, a practitioner expert gave a value of $X \geq 42$ with a very feasible, and the results of the questionnaire responses by students obtained value $\mathrm{X} \geq 33$ with a very decent category. Then it was concluded that teaching material in the form of Student Worksheets on the developed Environmental pollution material was very feasible to use.

Practical testing of the product trial phase showed a very practical category. So, it was concluded that Problem Based Instruction based student worksheets teaching materials on environmental pollution material developed were practically used in the learning process.

\section{REFERENCES}

Budiono, Eko \& Susanto, H. (2006). Penyusunan dan Penggunaan LKPD Pembelajaran Berdasarkan Kurikulum Berbasis Kompetensi Sub Pokok Bahasan Analisa Kuantitatif Untuk Soal-soal Dinamika Sederhana pada Kelas X Semester 1 SMA. Jurnal Pendidikan Fisika Indonesia. Vol 4, No. $2: 79-87$

Dewi, T. A. (2016). Penerapan Model Problem Based Instruction Untuk Meningkatkan Hasil Belajar Mahasiswa pada Mata Kuliah Ekonomi Pembangunan. Jurnal Promosi, Vol 4, No. 1 : 35-45.

Diniaty, A., \& Atun, S. (2015). Pengembangan Lembar Kerja Peserta Didik (LKPD) Industri Kecil Kimis Berorientasi Kewirausahaan Untuk SMK. Jurnal Inovasi Pendidikan IPA, Vol 1, No. 1 : 46-56.
Ermi, N. (2016). Penggunaan Media Lembar Kerja Siswa (LKS) dalam Meningkatkan Hasil Belajar Sosiologi Siswa Kelas XI SMAN 15 Pekanbaru. jurnal pendidikan, Vol 4, No. 1 : 39-41.

Ikhsan, M., Sutarno, \& Prayitno, B. A. (2016). Pengembangan Modul Berbasis Inkuiri Terbimbing pada Materi Sistem Gerak Manusia untuk Meningkatkan Hasil Belajar Siswa Kelas XI MIA SMA Negeri 1 Wera Kabupaten Bima Nusa Tenggara Barat. Jurnal Inkuiri, Vol 5, No. 1 : 133-142.

Lasmiyati, Idris, Harta. (2014). Pengembangan Modul Pembelajaran Untuk Meningkatkan Pemahaman Konsep dan Minat Siswa. Jurnal Pendidikan Matematika. Vol. 9, No. 2: 161-174.

Mardapi, D. (2007). Teknik Penyusunan Instrumen Tes dan Non Tes. Yogyakarta: Mitra Cedikia Press.

Marsa, Hala, Y., \& Mushawwir, A. T. (2016). Pengaruh Penggunaan Lembar Kerja Peserta Didik Berbasis Pendekatan Ilmiah Terhadap Aktivitas dan Hasil Belajar IPA Biologi Kelas VII Pesrta Didik SMP Negeri 2 Watampone. Jurnal Sainsmat, Vol 5, No. $1: 42-57$.

Martiningsih, Dkk (2018). Development Of Module Bsed On Scientific Contextual Additives Material Ton Increase Learning Outcomes And Science Process Skills In Junior High School. Juornal Of Innovative Science Education.Vol, 7, No. 2 :372-381.

Muhammad, W.D. (2017). Pengembangan Lembar Kerja Peserta Didik pembelajaran Biologi Berbasis Pendekatan Saintifik Untuk Meningkatkan Hasil Belajar Siswa. Journal of EST, Vol 3, No. 2 : 102-112. 
Sani, R.A., Manurung, S. R., Hary, S., \& Sudiran. (2018). Penelitian Pendidikan. Tangerang: Tira Smart

Susiolo, A. Dkk. (2016). Pengembangan LKPD Berbasis Pembelajaran Saintifik Untuk Meningkatkan Kemampuan Mencipta Siswa Dalam Proses Pembelajaran Akutansi Siswa Kelas XII SMA N 1 Slogohimo. Jurnal Pendidikan Ilmu Sosial. Vol 2, No. $1: 22-32$

Zubaidah, S. (2017). Keterampilan Abad Ke 21: Keterampilan Yang Diajarkan Melalui Pembelajaran. Malang: Universitas Negeri Malang. 